\author{
Goce Spasovski \\ Raymond Vanholder \\ Bruno Allolio \\ Djillali Annane \\ Steve Ball \\ Daniel Bichet \\ Guy Decaux \\ Wiebke Fenske \\ Ewout Hoorn \\ Carole Ichai \\ Michael Joannidis \\ Alain Soupart \\ Robert Zietse \\ Maria Haller \\ Sabine van der Veer \\ Wim Van Biesen \\ Evi Nagler
}

\section{Erratum to: Clinical practice guideline on diagnosis and treatment of hyponatraemia}

Published online: 30 July 2014

(C) Springer-Verlag Berlin Heidelberg and ESICM 2014

The online version of the original article can be found under doi:10.1007/s00134-014-3210-2.

G. Spasovski

State University Hospital Skopje, Zkopje, Macedonia

R. Vanholder · W. Van Biesen (

Ghent University Hospital, Ghent, Belgium

e-mail: Wim.VanBiesen@UGent.be

B. Allolio - W. Fenske

Würzburg University Hospital, Würzburg, Germany

D. Annane

Raymond Poincaré Hospital, University of Versailles Saint

Quentin, Paris, France

S. Ball

Newcastle Hospitals and Newcastle University, Newcastle, UK

D. Bichet

Consultant Nephrologist, Sacré-Coeur Hospital,

University of Montreal, Montreal, Canada

G. Decaux · A. Soupart

Erasmus University Hospital, Brussels, Belgium

E. Hoorn · R. Zietse

Erasmus Medical Centre, Rotterdam, The Netherlands

C. Ichai

Nice University Hospital, Nice, France

M. Joannidis

Innsbruck University Hospital, Innsbruck, Austria
M. Haller $\cdot$ S. van der Veer $\cdot$ E. Nagler

ERBP Methods Support Team, Ghent University Hospital, Ghent, Belgium

\section{Haller}

KH Elisabethinen Linz, Linz, Austria

S. van der Veer

Centre for informatics, Amsterdam Medical Centre, Amsterdam,

The Netherlands

\section{Erratum to: Intensive Care Med (2014) 40:320-331 DOI 10.1007/s00134-014-3210-2}

The electronic supplementary material of this article contained two errors.

\section{Correction 1}

In column 2 of Table 7, the last disorder under "Pulmonary disorders" should be "Respiratory failure associated with positive-pressure breathing" and not as published.

\section{Correction 2}

Only SI units should be used in the equation for estimates of the serum sodium concentration corrected for the presence of hyperglycaemia and not as published. The correct equation is as follows:

$$
\begin{aligned}
& \text { Corrected serum }\left(\mathrm{Na}^{+}\right) \\
& =\text {measured }\left(\mathrm{Na}^{+}\right)+2.4 \times \frac{(\text { glucose }(\mathrm{mmol} / \mathrm{l})-100(\mathrm{mmol} / \mathrm{l}))}{100(\mathrm{mmol} / \mathrm{l})} \\
& \text { Corrected }\left(\mathrm{Na}^{+}\right) \\
& =\operatorname{measured}\left(\mathrm{Na}^{+}\right)+2.4 \times \frac{(\text { glucose }(\mathrm{mmol} / \mathrm{l})-5.5(\mathrm{mmol} / \mathrm{l}))}{5.5(\mathrm{mmol} / \mathrm{l})}
\end{aligned}
$$

